\title{
The ambiguity about death in Japan: an ethical implication for organ procurement
}

\author{
John Robert McConnell, III The University of Tennessee, Knoxville, Tennessee
}

\begin{abstract}
In the latter half of the twentieth century, developed countries of the world have made tremendous strides in organ donation and transplantation. However, in this area of medicine, fapan has been slow to follow. Fapanese ethics, deeply rooted in religion and tradition, have affected their outlook on life and death. Because the fapanese have only recently started to acknowledge the concept of brain death, transplantation of major organs has been hindered in that country. Currently, there is a dual definition of death in fapan, intended to satisfy both sides of the issue. This interesting paradox, which still stands to be fully resolved, illustrates the contentious conflict between medical ethics and medical progress in fapan.
\end{abstract}

(Fournal of Medical Ethics 1999;25:322-324)

Keywords: Organ transplantation; brain death; Japan

\section{Introduction}

In 1968, the first heart transplant was attempted in Japan; that was to be the last for over a quarter of a century. In an unfortunate display of irony, the Japanese surgeon who should have been heralded as a pioneer of an operation that would save thousands of lives was instead charged with murder of the donor and criminal allegations were made that would inhibit all further attempts in the years to come. This predicament, however, stems from Japanese ethics that were established many years ago. Religion has a profound influence in Japan, one that dictates the Japanese attitude towards life, as well as their beliefs about death. Undeniably, this phenomenon has its beneficial effects. Yet in a seemingly technologically advanced society, it also provokes adverse consequences when confronted with developments at odds with popular belief, as the issue of organ transplantation illustrates. The ethical and spiritual foundations of the Japanese mentality have hindered the progress of transplantation in Japan, sacrificing thousands of lives each year, and thus invoking a reevaluation of their ideals.

\section{Japanese religion}

To understand the fierce debate over transplant tion that has plagued Japan for over a quarter of century, one must examine the religious beliefs that have precipitated this ethical dilemma. The major religions of Japan are Shinto, Taoism, Corio fucianism, and Buddhism. ${ }^{1}$ While these religions are unique and often practised separately in the world, the typical Japanese household oftent adopts a combination of their traditions. For example, Shinto's emphasis on the present is dominant that it does not address rituals of customs upon the death of a follower. Cons quently, many Shinto priests observe Taoist an $\mathbb{Q}$ Buddhist practices to consecrate the dead. BE cause of the religious overlap in many of the Jap nese traditions, as with this one regarding the treatment of the dead, a study of each religiom and, specifically, how they play a role in their at tude towards transplantation, is critical.

The majority of the population practises Shint $\vec{\Theta}_{\text {}}$ which is indigenous to Japan. The preservation of life, the promotion of good health, and the harmonisation with nature in accordance with the way of the kami, or Japanese divinities, are the three basic goals of Shinto. These principles of the Shinto faith place such a priority on life that the extraction of organs from a donor's body acceptable as long as it is saving or bettering a human life; otherwise, it is deemed sacrilegious Living donor transplants, such as a kidney or pa? tial liver, and cadaverous transplants, such as skip grafts and corneas, are permitted and frequentiy used. ${ }^{2}$ Yet it is because of these same principles that the determination of death has been fiercety debated in Japan. Shinto followers believe that declare death while the heart is still beating is pre mature, as well as unnatural; again, nature is pars mount in their beliefs. This has been the greatest obstacle in their acceptance of brain death, which is absolutely necessary for the transplantation of vital organs such as the heart and liver.

Taoism and Confucianism are religions that have migrated from China and have greatly influ enced the ethics of Japan. Confucius taught the् mankind possessed a general goodness an 
encouraged the suppression of individual desires in order to benefit humanity. Through the virtue of jen, or kindness, the idea of organ transplantation is supported. However, Taoism also affects many Japanese beliefs and customs, especially the attitude towards the afterlife. Basically, Taoism suggests that the human body is a microcosm of the universe. Taoists believe that the body must be preserved to provide the soul with a resting-place upon death, to ensure immortality. Accordingly, Taoist priests have incorporated complicated, and sometimes elaborate, rituals to channel lifeenhancing spirits into the body. To mutilate any of the body parts, for instance, by the extraction of organs, would be considered heretical. Naturally, this has also contributed to the conflict between cultural tradition and modern practicality.

The Mahayana form of Buddhism plays a minor, yet significant role in Japanese ethics, particularly in funeral proceedings and the belief in an afterlife. The goal of the Buddhists is to acquire nirvana, or rebirth; they are on a never-ending quest for enlightenment. Similar to Taoism, Buddhism has developed complicated rituals for the procurement of an afterlife. In addition, Buddhists tend to hold a somewhat pacifist attitude towards the present life, resulting in a lack of motivation to donate or receive tissue or organs for transplantation.

\section{Death's ambiguity in Japan}

The blend of Shinto, Taoist, Confucian and Buddhist beliefs in Japanese society has culminated in a social consensus that organ transplantation devalues life, as well as the afterlife. While the majority of the medical establishment in Japan have suppressed these cultural attitudes in favour of the concept of brain death and organ transplantation, the vast elderly population continues to uphold these traditional values. In combination with the tremendous respect that is displayed towards the elderly and their traditional values, there is a general mistrust of the Japanese medical profession that has made government officials reluctant to grant Japanese surgeons more authority in the determination of death and organ transplantation.

The recent effect of the Japaneses' inability to accept brain death has been profound. It has hampered the opportunity for Japanese citizens who need heart, lung and liver transplants to receive them, especially those of lower economic status. In order to have such a transplant Japanese citizens must travel outside the country to places such as India, Australia, and the United States. Sometimes, this requires the purchase of organs, as well. Prior to 1980 , an effort was made by the
Japanese medical community to study a proposition accepting brain death. ${ }^{3}$ The prerequisite of brain death, according to the Japanese study, was the evidence of a gross primary brain lesion. The criteria for this diagnosis were deep coma, apnoea, bilateral dilated pupils, absent pupillary and corneal reflexes, isoelectric electroencephalograms (EEGs), and persistent hypotension, with blood pressure $40 \mathrm{mmHg}$ below normal. At that time, only four per cent of the Japanese subjects involved in the study met the criteria and retrospective studies indicate that they were all diagnosed accurately, as having complete cessation of brain activity that was irretrievable. Evidently, this study did nothing to affect attitudes towards transplantation at the time. However, growing public concern about the necessity of organ transplants escalated in the 1990s. One case that received widespread media coverage in Japan was the death of Miyuki Monobe, an eight-yearold girl awaiting a heart transplant. The medical establishment fed her story to the media to strengthen public sentiment in favour of transplantation. ${ }^{4}$

Until recently, Japan, along with Poland and Pakistan, discouraged the concept of brain death. However, in April 1997, the lower diet of the Japanese parliament approved a measure which would legalise the determination of death by EEG. Although this same bill was rejected by the upper diet, a resolution was passed in June 1997 in an effort to compromise between those who accepted brain-death determination and those who rejected it. The result, much to the dismay of the medical establishment, is a dual definition of death in Japan. ${ }^{5}$ In order to allow heart and lung transplants, Japan has legalised brain death when the deceased is an organ donor; in cases where the deceased is not a donor, the time of death is recorded when the heart stops beating. This unusual stance has created a double standard on the determination of death that has added to the bureaucracy involved in Japanese medical care. The donor must consent to the diagnosis of brain death prior to death and garner the support of his or her family. In addition, the cessation of brain activity must be declared by two or more physicians who are not participating in the actual procurement or transplantation of the organs. While this resolution is a step in the right direction in the eyes of the Japanese, as indicated by recent polls, its stringent conditions will probably keep the number of heart, lung and liver transplant operations to a minimum. It remains to be seen whether, as the older generation, with its conservative attitude towards brain death and organ 
procurement, dies, greater acceptance of and an inverse in Japanese organ transplantation will result.

\section{Acknowledgments}

I thank the University of Tennessee at Knoxville, particularly the Philosophy Department, for use of its resources.

Fohn Robert McConnell, III is a student at the University of Tennessee.

\section{References}

1 Craven J, Rodin G, eds. Psychiatric aspects of organ transplant tion. New York: Oxford University Press, 1992.

2 Pallis C. $A B C$ of brainstem death [2nd ed]. London: BMJ Puछ lishing Group, 1996.

3 National Institute of Neurological and Communicative Diso ders and Stroke. The NINCDS collaborative study of brain deaf Bethesda: National Institute of Health, 1980.

4 Jordan M. Brain-death bill passes easily in Japanese House. The Washington Post 1997 Apr 25: sect A:36 (col 1).

5 WuDunn S. Japanese lawmakers vote to allow heart and lung transplants. The New York Times 1997 June 18: sect A: 6 (col 29 